\title{
PERLINDUNGAN HUKUM TERHADAP AHLI WARIS ATAS UANG PERTANGGUNGAN ASURANSI JIWA (Studi Kasus Putusan Pengadilan Negeri Lubuk Pakam Nomor : 10/Pdt.G/2015/PN Lbp)
}

\author{
Oleh: \\ Alusianto Hamonangan ${ }^{1)}$, \\ Ria Sintha Devi ${ }^{2)}$ \\ Melky Saro Bulyan Zebua ${ }^{3)}$, \\ Universitas Darma Agung, Medan ${ }^{1,2,3)}$ \\ E-mail: \\ $\frac{\text { alusiantoh710@gmail.com }}{\text { riasinthadevi04@gmail.com }}{ }^{2}$, \\ key3saro@gmail.com ${ }^{3)}$
}

\begin{abstract}
Life insurance is an insurance, whereby an insurer binds himself to an insured person, by receiving a premium, to provide reimbursement due to a death event. Study and analyze the heirs whose names do not recommend as beneficiaries in a life insurance policy to which the heirs have responded as heirs. Indication of wishes to the insured party's wishes submitted in the SPAJ and agreed upon in an agreement document called an Insurance Policy. In this study raised the title Legal Protection Against Inheritance Who Is Not Designated in Life Insurance Policy (Study District Court Decision Number: 10 / Pdt.G / 2015 / PN Lbp). The formulation of the problem in this research, first how are the beneficiaries in life insurance after the insured dies (District Court Decision Number: 10 / Pdt.G / 2015 / PN Lbp)? Second, how are the legal efforts of the heirs appointed to get the right to money? life insurance coverage as inheritance (District Court Decision Number: 10 / Pdt.G / 2015 / PN Lbp)?, three, how is the legal protection in the decision that decides the inheritance rights to life insurance coverage money (District Court Decision Number: 10 / Pdt.G / 2015 / PN Lbp)?. This type of research is a normative legal approach method, the nature of this research is descriptive in accordance with the problem and research objectives.The results of the study investigated the consideration that the judge's consideration in making the decision number: 10 / Pdt.G / 2015.PN Lbp, based on several considerations, the judge examined arguments, letters, certificates and decided that the sum insured was an inheritance that the panel of judges ordered and passed guided by arguments, evidence and evidence submitted in the trial. The judge's decision obtains a stipulation regarding the legal heir for the party who wins the case, obtains legal certainty regarding the status of inheritance ownership in the form of compensation from life insurance. As a recipient of life insurance funds, they have an administration because the heirs are actually the heirs regulated in the Civil Code and determined by a judge's decision. The judge's decision obtains a stipulation regarding the legal heir for the winning party in the case, obtains legal certainty regarding the status of inheritance ownership in the form of compensation from life insurance to the legal heir.
\end{abstract}

Keywords: heirs, life insurance, judge's decision 


\begin{abstract}
ABSTRAK
Asuransi jiwa merupakan suatu pertanggungan, dengan mana seorang penanggung mengikatkan diri kepada seorang tertanggung, dengan menerima suatu premi, untuk memberikan penggantian karena suatu evenemen meninggal dunia. Mempelajari dan menganalisis ahli waris yang namanya tidak disebutkan sebagai penerima manfaat dalam polis asuransi jiwa yang telah ditinggalkan oleh pewaris sebagai ahli waris. Penunjukan didasarkan pada keinginan pihak tertanggung yang diajukan di dalam SPAJ dan disepakati di dalam sebuah dokumen perjanjian yang disebut Polis Asuransi. Dalam penelitian ini mengangkat judul Perlindungan Hukum Terhadap Ahli Waris Yang Tidak Ditunjuk Dalam Polis Asuransi Jiwa (Studi Putusan Pengadilan Negeri Nomor : 10/Pdt.G/2015/PN Lbp). Rumusan masalah dalam penelitian ini, pertama bagaimana kedudukan penerima manfaat dalam asurans jiwa setelah tertanggung meninggal dunia (Putusan Pengadilan Negeri Nomor : 10/Pdt.G/2015/PN Lbp)?, keduabagaimanaupaya hukum ahli waris yang tidak ditunjuk untuk mendapatkan hak atas uang pertanggungan asuransi jiwa sebagai harta warisan (Putusan Pengadilan Negeri Nomor : 10/Pdt.G/2015/PN Lbp)?, ketigabagaimana pelindungan hukum dalam putusan yang memutuskan hak waris atas uang pertanggungan asuransi jiwa (Putusan Pengadilan Negeri Nomor : 10/Pdt.G/2015/PN Lbp)?.Jenis penelitian ini adalah metode pendekatan hukum normatif, sifat penelitian ini adalah bersifat deskriptif sesuai dengan masalah dan tujuan penelitiannya. Hasil penelitian penelitian menunjukkan bahwa pertimbangan hakim dalam menjatuhkan putusan nomor : 10/Pdt.G/2015.PN Lbp, berdasarkan beberapa pertimbangan, hakim memeriksa dalil, surat, keterangan saksi dan memutusakan menetapkan bahwa uang pertanggungan merupakan harta waris yang majelis hakim memeriksa dan menjatuhkan putusan berpedoman pada dalil, saksi dan bukti yang diserahkan dalam persidangan. Putusan hakim memperoleh ketetapan mengenai ahli waris yang sah bagi pihak yang menang dalam perkara, memperoleh kepastian hukum tentang status kepemilikan harta waris yang berupa uang santunan dari asuransi jiwa. Sebagai penerima dana asuransi jiwa memiliki karakteristik administrasi karena ahli waris sebenarnya adalah ahli waris yang diatur dalam KUHPerdata dan ditetapkan oleh keputusan hakim. Putusan hakim memperoleh ketetapan mengenai ahli waris yang sah bagi pihak yang menang dalam perkara, memperoleh kepastian hukum tentang status kepemilikan harta waris yang berupa uang santunan dari asuransi jiwa kepada Ahli Waris yang sah.
\end{abstract}

\title{
Kata Kunci : ahli waris, asuransi jiwa, putusan hakim
}

\section{PENDAHULUAN}

$\begin{array}{llr}\text { Kita semua tahu } & \text { bahwa } \\ \text { manusia pada akhirnya akan } \\ \text { meninggalkan dunia ini untuk }\end{array}$ selamanya dan tidak ada yang tahu akan usia seseorang, sebab ajal dapat menjemput setiap saat. Jika seseorang pergi untuk selamanya (meninggal. "legitime portie," warisan. Dalam asuransi terdapat yang namanya manfaat asuransi yang merupakan uang santunan, uang santunan tersebut adalah sejumlah uang yang wajib dibayar oleh penanggung kepada penikmat dalam hal meninggalnya tertanggung sesuai dengan kesepakatan yang tercantum didalam polis.

Dalam "Konstruksi hukum waris dalam pasal 852 KUHPerdata telah menentukan ahli waris yang berhak mendapatkan bagian dari pewaris yaitu: golongan I (suami/isteri) yang hidup terlama dan 
anak/keturunannya; golongan II (orang tua dan saudara kandung pewaris; golongan III (keluarga dalam garis lurus ke atas sesudah bapak dan ibu pewaris; golongan IV. Dalam pemberlakuannya dikenal asas golongan I menutup golongan dua, golongan dua menutup golongan III golongan III dan IV dapat mewarisi bersama."Sedangkan dalam menentukan ahli waris penerima manfaat uang santunan ini tidak merujuk kepada pengaturan hukum mengenai ahli waris perdata. Penunjukan didasarkan pada keinginan pihak tertanggung yang diajukan di dalam SPAJ (Surat Pengajuan Asuransi Jiwa dan disepakati di dalam sebuah dokumen perjanjian yang disebut Polis Asuransi. Pihak tertanggung bebas menentukan siapa saja yang menjadi ahli warisnya dalam polis asuransi asalkan tetap merupakan Insurable Interest.

Namun jika penerima manfaat bukanlah ahli waris yang sah dari pewaris maka akan menimbulkan masalah seperti yang terdapat dalam Putusan Pengadilan Negeri Lubuk Pakam No.10/Pdt.G/2015/PN Lbp yang menimbulkan sengketa antara ahli waris dan penerima manfaat atas uang pertanggungan asuransi jiwa ketika pewaris (tertanggung) meninggal dunia sehingga memerlukan suatu keputusan hakim yang mengandung keadilan (ex aequo et bono) serta kepastian hukum.

Berdasarkan uraian latar belakang di atas, penulis merasa tertarik untuk meneliti dan mengkaji khusus mengenai hak waris atas uang pertanggungan jiwa, penulis tertarik mengambil judul judul :"PERLINDUNGAN HUKUM TERHADAP AHLI WARIS ATAS UANG PERTANGGUNGAN ASURANSI JIWA (Studi Kasus Putusan Pengadilan Negeri Lubuk
Pakam Nomor : 10/Pdt.G/2015/PN Lbp)".

\section{TINJAUAN PUSTAKA}

1. Hukum Waris

Istilah Hukum Waris dalam perdata barat disebut dengan Erfrecht.Hukum waris diatur di dalam Buku II KUHPerdata, yaitu Pasal 830 sampai dengan Pasal 1130.Hukum waris merupakan salah satu bagian dari hukum perdata secara keseluruhan dan merupakan bagian terkecil dari hukum keluarga.Pengertian waris

Secara umum di dunia ini, berlaku suatu asas bahwa hak waris itu berlaku setelah yang mewariskan meninggal dunia.Tidak terkecuali dalam hukum barat yakni dalam KUHPerdata.Pasal 830 KUHPerdata dikatakan, "Pewarisan hanya berlangsung karena kematian".

a. Unsur-Unsur Kewarisan

Anititus amanat mengatakan dalam hal kewarisan ada terdapat tiga unsur penting yaitu :

1) Pewaris (erflater)

2) Ahli waris (erfgenaam);

3) Harta peninggalan (boedel).

\section{Asuransi}

a. pengertian Asuransi

Dalam segi Hukum, telah diatur didalam Kitab Undang-Undang Hukum Dagang pada Pasal 246 menyebutkan untuk memberikan penggantian kepadanya karena suatu kerugian, kerusakan atau kehilangan keuntungan yang diharapkan yang mungkin akan dideritanya karena suatu peristiwa yang tak tertentu."

b. Perusahaan Asuransi

Perusahaan Asuransi adalah perusahaan asuransi umum dan perusahaan asuransi jiwa (Pasal 1 angka (15) UU No. 40/2014. 
c. Objek Asuransi

Objek Asuransi adalah jiwa dan raga, kesehatan manusia, tanggung jawab hukum, benda atau jasa, serta semua kepentingan lainnyayang dapat hilang, rusak, rugi, dan/atau berkurang nilainya.

d. Polis Asuransi

Polis asuransi merupakan dokumen yang berisi segala hal yang telah disepakati. Hal ini tercantum dalam pasal 255 Kitab Undang-Undang Hukum Dagang yang menyatakan bahwa : "Suatu pertanggungan harus dibuat secara tertulis dalam suatu akta yang dinamakan polis".

e. Manfaat (beneficiary) Asuransi

1) Pendistribusian biaya dan manfaat yang lebih adil;

2) Memberikan kepastian;

3) Sarana menabung;

4) Instrumen pengalihan dan penyebaran risiko;

5) Membantu meningkatkan kegiatan usaha Tertanggung.

\section{METODE PELAKSANAAN}

Untuk

membahas

permasalahan yang telah dirumuskan dan dibatasi sebagaimana tersebut diatas, maka dalam metode penyusunan dan penyelesaian peneliti dalam penelitian ini, akan dipergunakan metode dan teknik penelitian sebagaimana dibawah ini. Jenis penelitian yang digunakan dalam penelitian ini adalah yuridis normatif. Jenis data yang digunakan dalam penelitian ini merupakan data sekunder, dengan menggunakan sumber data dari Bahan hukum primer : :Kitab Undang-Undang Hukum Perdata, Kitab Undang-Undang Hukum Dagang, Undang- Undang No.40 Tahun 2014 Tentang Perasuransian. Putusan Pengadilan Negeri Nomor : 10/Pdt.G/2015/PN LbpTeknik. Bahan hukum sekunder :Buku-buku penelitian terdahulu, Jurnal, Artikel, Internet, dan lain-lain yang mendukung sumber data bahan hukum primer.

\section{HASIL DAN PEMBAHASANA}

\section{A.Kedudukan Penerima Manfaat Dalam Asuransi Jiwa Setelah Tertanggung Meninggal Dunia (Putusan Pengadilan Negeri Nomor : 10/Pdt.G/ PN Lbp). \\ Majelis Hakim dalam} menjatuhkan putusan pada perkara gugatan perbuatan melawan hukum yang melanggar hak subjekif seorang pewaris mengenai uang pertanggungan sebagai harta waris setelah pewaris meninggal dunia dalam Putusan Nomor : 10/Pdt.G/2015/PN Lbp, berdasarkan beberapa pertimbangan yaitu : majelis hakim memeriksa dan menjatuhkan putusan berpedoman pada dalil, saksi dan bukti yang diserahkan dalam persidangan.

KIEN NJEN atau disebut juga TJONG KIEN NJEN yang telah meninggal dunia pada hari Jumat tanggal 24 Agustus 2012 di Hospital Island Pulau Penang, maka Istri beserta anaknya yang masih dibawah umur tersebut adalah ahli waris dari almarhum Kien Njen dan tidak ada lagi ahli waris lainnya ;

Pada saat Kien Njen belum menikah, dirinya terdaftar sebagai peserta Asuransi Jiwa Prulink pada PT. Prudential Life Assurance (Tergugat III) dengan Nomor Polis : 25783625 dengan Tertanggung Utama Kien Njen dan jenis asuransi Prulink assurance account, dengan total premi bulanan sebesar Rp 1.000.000,00 (Satu Juta Rupiah) melalui pembayaran bulanan, dengan data calon Penerima Manfaat atas nama Karnen dan Mie Khim (Tergugat I dan Tergugat II). 
Nama penerima manfaat dalam Polis Asuransi tersebut ternyata tidak dirubah keatas namaPenggugat selaku anak dan istri yang sah walaupun kenyataannya secara fisik pembayaran premi lanjutan tersebut setelah berlangsungnya perkawinan dilakukan oleh Penggugat.

Tindakan Tergugat I dan Tergugat II yang tidak menyerahkan uang pertanggungan klaim meninggal dunia asuransi jiwa atas nama Kien Njen dengan tersebut kepada Penggugat padahal Tergugat I maupun Tergugat II mengetahui dengan pasti haknya hanya sekedar menerima uang karena namanya tercantum dalam Polis Asuransi sebagai calon penerima manfaat dan bukan untuk memilikinya sedangkan uang santunan asuransi tersebut sesungguhnya adalah milik dan kepunyaan Penggugat adalah nyatanyata merupakan perbuatan yang bertentangan dengan kewajiban hukum Tergugat I dan Tergugat II dan melanggar hak subjektif Penggugat, dan demikian juga tindakan Tergugat III yang menyerahkan uang pertanggungan polis asuransi jiwa atas nama suami dan ayah kandung Penggugat kepada Tergugat I dan Tergugat II tanpa melakukan penelitian dengan sungguhsungguh tentang siapa ahli waris yang berhak menerimanya adalah merupakan perbuatan yang bertentangan dengan kewajiban hukum Tergugat III yang juga nyata-nyata melanggar hak subjektif Penggugat, dan dengan demikian perbuatan Tergugat I, Tergugat II dan Tergugat III tersebut telah dapat dikwalifisir sebagai perbuatan melawan hukum yang menimbulkan kerugian bagi Penggugat.

Diperoleh fakta-fakta hukum sebagai berikut :

- Bahwa KIEN NJEN adalah suami Penggugat ;
- Bahwa Tergugat I dan II beserta almarhum KIEN NJEN adalah anak kadung dari TJONG YUN TJAU (Penggugat Intervensi) dan alm. TJUNG ;

- Bahwa pada tahun 2007 KIEN NJEN terdaftar sebagai peserta Asuransi Jiwa Prulink pada PT. Prudential Life Assurance (Tergugat III) dengan Nomor Polis : 25783625 dengan Tertanggung Utama Kien Njen, dengan total premi bulanan sebesar Rp 1.000.000,00 (Satu Juta Rupiah) melalui pembayaran bulanan, dengan data calon Penerima Manfaat atas nama Karnen dan Mie Khim (Tergugat I dan Tergugat II) ;

- Bahwa Kien Njen tidak dapat menerima dan menikmati manfaat asuransinya tersebut secara langsung dikarenakan telah meninggal dunia, yang mana uang pertanggungan klaim meninggal dunia asuransi jiwa atas nama Kien Njen sebesar Rp 599.193.062, 22 (Lima Ratus Sembilan Puluh Sembilan Juta Seratus Sembilan Puluh Tiga Ribu Delapan Puluh Enam Rupiah Dua Puluh Sen) tersebut telah diserahkan oleh Tergugat III kepada Tergugat I dan Tergugat II ;

- Untuk membuktikan dalil-dalil gugatannya Penggugat telah mengajukan bukti surat, dimana Majelis Hakim akan mempertimbangkan bukti-bukti tersebut satu persatu serta hubungannya satu sama lain, dihubungkan dengan dalil-dalil gugatan Penggugat sendiri ;

Karena perkawinan Penggugat dengan KIEN NJEN tersebut telah dinyatakan sah secara hukum, maka anak yang lahir di dalam atau sebagai 
akibat dari perkawinan tersebut adalah anak yang sah, sebagaimana ditentukan dalam Pasal 42 Undang-undang Nomor 1 Tahun 1974 tentang Perkawinan.

Majelis Hakim berpendapat, jelas terlihat hubungan hukum antara Penggugat, KIEN NJEN dan Shellyna Evelyn, yaitu hubungan hukum kekeluargaan

Premi asuransi tersebut telah dibayar oleh KIEN NJEN sebelum melangsungkan perkawinan dengan Penggugat, dimana setelah perkawinan terjadi, maka premi asuransi tersebut, telah dibayarakan baik oleh Penggugat maupun oleh KIEN NJEN sendiri. Hal mana telah dibuktikan pula oleh Kuasa Hukum Penggugat berdasarkan

\section{Tergugat III telah} membenarkan telah membayarkan polis asuransi tersebut.Perihal Penggugat dan anak yang lahir dari perkawinan Penggugat dan KIEN NJEN tersebut sebagai ahli waris KIEN NJEN, telah dibuktikan pula oleh Penggugat.

Menimbang, bahwa berdasarkan pada ketentuan Pasal 830 KUHPerdata yang menyebutkan bahwa "Perwarisan hanya berlangsung karena kematian", dimana ada 2 (dua) syarat yang harus dipenuhinya untuk dapat memiliki hak mewarisi, yaitu :

1) Harus ada orang yang meninggal dunia, dan

2) Untuk memperoleh harta peninggalan, orang harus hidup pada saat pewaris meninggal dunia

Majelis Hakim berpendapat bahwa polis asuransi tersebut merupakan harta peninggalan KIEN NJEN yang harus diwariskan kepada ahli warisnya, oleh karena dengan meninggalnya KIEN NJEN maka warisannya telah terbuka sebagaimana ditentukan dalam Pasal 830 KUHPerdata.

$$
\text { Petitum gugatan Penggugat }
$$

point 5 yang memohon untuk menyatakan tindakanTergugat III menyerahkan uang pertanggungan klaim meninggal dunia asuransi jiwa atas nama Kien Njen dengan Nomor Polis 25783625 sebesar Rp 599.193.062, 22 (Lima Ratus Sembilan Puluh Sembilan juta seratus sembilan puluh tiga ribu delapan puluh enam rupiah dua Puluh Sen) tersebut kepada Tergugat I dan Tergugat II, serta tindakan Tergugat I dan tindakan Tergugat I dan Tergugat II menerima penyerahan uang pertanggungan klaim meninggal dunia asuransi jiwa atas nama Kien Njen padahal bukan sebagai ahli waris yang sah dan berhak menerimanya adalah merupakan perbuatan melawan hukum (Onrecht Matigedaan) dengan segala akibat hukumnya, oleh karena akibat perbuatan Tergugat I dan II tersebut membawa kerugian bagi Penggugat dan juga telah melanggar hak subjektif Penggugat, maka menurut Majelis Hakim petitum tersebut patutlah untuk dikabulkan.

Tergugat II menerima penyerahan uang pertanggungan klaim meninggal dunia asuransi jiwa atas nama Kien Njen padahal bukan sebagai ahli waris yang sah dan berhak menerimanya adalah merupakan perbuatan melawan hukum (Onrecht Matigedaan) dengan segala akibat hukumnya, oleh karena akibat perbuatan Tergugat I dan II tersebut membawa kerugian bagi Penggugat dan juga telah melanggar hak subjektif Penggugat, maka menurut Majelis Hakim petitum tersebut patutlah untuk dikabulkan 


\section{B.Perlindungan Hukum Terhadap Ahli Waris Atas Uang Pertanggungan ASURANSI JIWA(Putusan Pengadilan Negeri Nomor : 10/Pdt.G/2015/Pn Lbp).}

\section{Penyelesaian Sengketa di Luar Pengadilan (Non Litigasi)}

Menurut terminologi hukum acara perdata, mediasi adalah proses penyelesaian awal yang wajib diikuti oleh para pihak atas perkara yang telah didaftar ke pengadilan. Sebelum hakim memeriksa perkara yang diajukan, majelis hakim mewajibkan para pihak yang berperkara untuk menempuh upaya mediasi terlebih dahulu. Intinya, mediasi adalah proses penyelesaian awal dari suatu perkara perdata yang telah didaftarkan ke pengadilan.Ketentuan mediasi diatur dalam Peraturan Mahkamah Agung Nomor 1 Tahun 2016 tentang Prosedur Mediasi di Pengadilan ("Perma 1/2016").Menurut Pasal 1 angka 1 Perma 1/2016, mediasi adalah cara penyelesaian sengketa melalui proses perundingan untuk memperoleh kesepakatan para pihak dengan dibantu oleh mediator. Kewajiban untuk melakukan mediasi sangat tegas diperintahkan oleh peraturan ini.Pada Pasal 17 ayat (1) Perma 1/2016 menegaskan bahwa pada hari sidang yang telah ditentukan dan dihadiri oleh para pihak, hakim pemeriksa perkara mewajibkan para pihak untuk menempuh mediasi.

Para pihak telah mengupayakan Mediasi sesuai dengan Mediator SAMUEL GINTING, SH., dan berdasarkan Laporan Mediator tertanggal 02 Juli 2015, mediasi tersebut belum berhasil dan oleh karena itu juga sesuai dengan Pasal $154 \mathrm{RBg}$ Majelis Hakim tetap mengupayakan perdamaian antara kedua belah pihak yang berpekara, tetapi para pihak berketetapan untuk melanjutkan perkara ini.

\section{Penyelesaian Sengketa di Pengadilan (Litigasi)}

\section{Gugatan Penggugat}

Henriyani dan Shellyna

Evelyn (Penggugat) melakukan upaya hukum dengan surat gugatan tanggal 23 Januari 2015 yang diterima dan didaftarkan di Kepaniteraan Pengadilan Negeri Lubuk Pakam pada tanggal 26 Januari 2015 dalam Register Nomor 10/PDT.G/2015/PN Lbp, telah mengajukan gugatan sebagai berikut, Penggugat adalah istri dan anak kandung dari KIEN NJEN atau disebut juga TJONG KIEN NJEN, Tempat/ Tanggal Lahir Mulio Rejo/ 19 Mei 1972 sebagaimana diuraikan dalam Kutipan Akta Perkawinan Nomor : 729/2010 tanggal 06 Oktober 2010 Jo. Kutipan Akta Kelahiran Nomor : 7.717/U/Mdn/2010 tanggal 30 November 2010.

Kien Njen tersebut telah meninggal dunia pada hari Jumat tanggal 24 Agustus 2012 di Hospital Island Pulau Penang sebagaimana diuraikan dalam Surat Keterangan yang diterbitkan Konsulat Jenderal R.I Penang Nomor : 1026/04/VIII/2012 tanggal 27 Agustus 2012 Jo. Surat Kematian yang diterbitkan / oleh Kepala Desa Muliorejo Nomor : 474.3/180 tanggal 03 September 2012; maka berdasarkan Surat Pernyataan Ahli Waris tertanggal 07 Desember 2012 yang turut disaksikan serta diketahui Kepala Dusun XV maupun Kepala Desa Muliorejo yang diperbuat diatas kertas bermaterai cukup dan dipertegas kembali dalam Surat Keterangan Ahli Waris yang dituangkan dalam Akta Nomor : 05 tanggal 08 April 2013 yang diperbuat dihadapan dan oleh Dicki Petrus Sebayang, SH, Notaris di Medan serta Surat 
Keterangan

Nomor

W2.AHU.2.AH.06.09-34 tanggal 18

Nopember 2013 yang diperbuat dan ditanda tangani oleh Kepala Balai Harta Peninggalan Medan, telah dinyatakan dengan tegas bahwasanya Penggugat beserta anaknya yang masih dibawah umur tersebut diatas adalah ahli waris dari almarhum Kien Njen dan tidak ada lagi ahli waris lainnya ;

Kien Njen yakni pada saat Status Perkawinannya Belum Menikah, suami/ ayah kandung dari Penggugat tersebut terdaftar sebagai peserta Asuransi Jiwa-Prulink pada PT. Prudential Life Assurance (Tergugat III) dengan Nomor Polis : 25783625 dengan Tertanggung Utama Kien Njen dan jenis asuransi Prulink assurance account, dengan total premi bulanan sebesar Rp 1.000.000.- (Satu Juta Rupiah) melalui pembayaran bulanan, dengan data calon Penerima Manfaat atas nama Karnen dan Mie Khim (Tergugat I dan Tergugat II) sebagaimana diuraikan dalam SPAJ/Proposal Nomor : 61361054 tanggal 01 Mei 2007 melalui Agen/FSC Nomor : 00066392 atas nama Susanto dan unit Keagenan/Sales atas nama Nurjafa dan diproses Kantor Pusat PT. Prudential pada tanggal 08 Mei 2007 dengan nomor polis sebagaimana diuraikan diatas.

Sekalipun pada tanggal 29 Mei 2010 sebagaimana diuraikan dalam Akta Perkawinan Nomor : 729/2010 tanggal 06 Oktober 2010 Kien Njen telah menikah dan selanjutnya telah lahir anak sebagaimana diuraikan dalam Kutipan Akta Kelahiran Nomor : 7.717/U/Mdn/2010 tanggal 30 November 2010, namun nama penerima manfaat dalam Polis Asuransi tersebut ternyata tidak dirobah keatas nama Penggugat selaku anak dan istri yang sah walaupun kenyataannya secara fisik pembayaran premi lanjutan tersebut setelah berlangsungnya perkawinan dilakukan oleh Penggugat.

Tergugat I dan Tergugat II tersebut adalah adik dan kakak kandung Kien Njen yang merupakan adik ipar serta kakak ipar Penggugat, dikarenakan telah meninggal dunia sebagaimana ternyata dari surat kematian yang diuraikan diatas, dan sebagai ahli warisnya Penggugat sekitar bulan Nopember 2012 mendatangi kantor Tergugat III dengan maksud untuk meminta brosur dan persyaratan pengajuan klaim manfaat atas Polis Asuransi suaminya tersebut diatas dengan harapan dari pembayaran klaim manfaat Prulink tersebut dapat dimanfaatkan untuk pembayaran hutang atas biaya perobatan dan biaya-biaya lainnya yang berkaitan dengan meninggal dunianya suami dan ayah kandung Penggugat tersebut, dan alangkah terkejutnya Penggugat ketika mendapat penjelasan tentang uang pertanggungan klaim meninggal dunia asuransi jiwa atas nama Kien Njen dengan Nomor Polis 25783625 sebesar Rp 599.193.062, 22 (Lima Ratus Sembilan Puluh Sembilan Juta Seratus Sembilan Puluh Tiga Ribu Delapan Puluh Enam Rupiah Dua Puluh Sen) tersebut telah diserahkan kepada Tergugat I dan Tergugat II, tetapi kemudian pada kenyataannya Tergugat I dan Tergugat II tidak menyerahkannya kepada Penggugat sebagai pihak yang berhak memilikinya ;

Tindakan yang tidak menyerahkan uang pertanggungan klaim meninggal dunia asuransi jiwa tersebut kepada Penggugat padahal Tergugat I maupun Tergugat II mengetahui dengan pasti haknya hanya sekedar menerima uang karena namanya tercantum dalam Polis Asuransi sebagai calon penerima manfaat dan bukan untuk memilikinya sedangkan uang santunan asuransi 
tersebut sesungguhnya adalah milik dan kepunyaan Penggugat adalah nyatanyata merupakan perbuatan yang bertentangan dengan kewajiban hukum Tergugat I dan Tergugat II dan melanggar hak subjektif Penggugat, dan demikian juga tindakan Tergugat III yang menyerahkan uang pertanggungan polis asuransi jiwa atas nama suami dan ayah kandung Penggugat kepada Tergugat I dan Tergugat II tanpa melakukan penelitian dengan sungguhsungguh tentang siapa ahli waris yang berhak menerimanya adalah merupakan perbuatan yang bertentangan dengan kewajiban hukum Tergugat III yang juga nyata-nyata melanggar hak subjektif Penggugat, dan dengan demikian perbuatan Tergugat I,Tergugat II dan Tergugat III tersebut telah dapat dikwalifisir sebagai perbuatan melawan hukum yang menimbulkan kerugian bagi Penggugatsebagaimana kriteria perbuatan melawan hukum yang diintradusir dalam putusan perkara Lindan Baum Choken Arrest H.R 1919 yang dipertegas kembali dalam pasal 1365 KUHPerdata dengan segala akibat hukumnya.

\section{Petitum dari Penggugat}

Petitum berisi tuntutan apa saja yang dimintakan oleh penggugat kepada hakim untuk dikabulkan. Supaya gugatan sah, dalam arti tidak mengandung cacat formil, harus mencantumkan petitum gugatan yang berisi pokok tuntutan penggugat, berupa deskripsi yang jelas menyebut satu per satu dalam akhir gugatan tentang halhal apa saja yang menjadi pokok tuntutan penggugat yang harus dinyatakan dan dibebankan kepada tergugat. Berikut adalah petitium yang diajukan penggugat pada putusan No.10/Pdt.G/2015/PN Lbp :

\section{Putusan Hakim}

Memperhatikan UndangUndang Nomor 49 Tahun 2009 tentang Peradilan Umum dan peraturanperaturan lain yang bersangkutan;

MENGADILI :

DALAM PERKARA POKOK

DALAM KONVENSI

DALAM EKSEPSI

- Menolak eksepsi Tergugat I dan II untuk seluruhnya;

DALAM POKOK PERKARA

1. Mengabulkan gugatan Penggugat untuk sebahagian ;

2. Menyatakan Penggugat bersamasama dengan Shellyna Evelyn adalah ahli waris yang sah dari Kien Njen yang telah meninggal dunia di Hospital Island Pulau Penang pada tanggal 24 Agustus 2012;

3. Menyatakan Penggugat adalah pihak yang berhak menerima pembayaran uang pertanggungan klaim meninggal dunia asuransi jiwa atas nama Kien Njen dengan Nomor Polis 25783625 sebesar Rp 599.193.062, 22 (Lima Ratus Sembilan Puluh Sembilan Juta Seratus Sembilan Puluh Tiga Ribu Delapan Puluh Enam Rupiah Dua Puluh Sen) tersebut dari Tergugat III ;

4. Menyatakan tindakan Tergugat III menyerahkan uang pertanggungan klaim meninggal dunia asuransi jiwa atas nama Kien Njen dengan Nomor Polis 25783625 sebesar Rp 599.193.062, 22 (Lima Ratus Sembilan Puluh Sembilan juta seratus sembilan puluh tig ribu delapan puluh enam rupiah dua Puluh Sen) tersebut kepada Tergugat I dan Tergugat II, serta tindakan Tergugat I dan Tergugat II menerima penyerahan uang pertanggungan klaim meninggal dunia asuransi jiwa atas nama Kien Njen padahal bukan sebagai ahli 
waris yang sah dan berhak menerimanya adalah merupakan perbuatan melawan hukum (Onrecht Matigedaan) dengan segala akibat hukumnya;

5. Menghukum para Tergugat III untuk menagih kembali uang pertanggungan klaim meninggal dunia asuransi jiwa atas nama Kien Njen dengan Nomor Polis 25783625 sebesar Rp 599.193.062, 22 (Lima Ratus Sembilan Puluh Sembilan Juta Seratus Sembilan Puluh Tiga Ribu Delapan Puluh Enam Rupiah Dua Puluh Sen) yang telah diserahkan kepada Tergugat I dan Tergugat II tersebut atau setidaktidaknya menghukum Tergugat I dan II untuk menyerahkan uang pertanggungan klaim meninggal dunia asuransi jiwa atas nama Kien Njen dengan Nomor Polis 25783625 sebesar Rp 599.193.062, 22 (Lima Ratus Sembilan Puluh Sembilan Juta Seratus Sembilan Puluh Tiga Ribu Delapan Puluh Enam Rupiah Dua Puluh Sen) tersebut kepada Penggugat seketika, tunai dan tanpa syarat ;

6. Menolak Gugatan Penggugat selain dan selebihnya ;

DALAM REKONVENSI

- Menolak gugatan Rekonvensi Penggugat dr/Tergugat I dan II dk untuk seluruhnya ;

DALAM KONVENSI dan REKONVENSI ;

- Menghukum Penggugat dalam Rekonvensi/ Tergugat I dan II dalam konvensi, Tergugat III secara tanggung renteng untuk membayar ongkos perkara sejumlah Rp.1.716.000,00 (satu juta tujuh ratus enam belas ribu rupiah);

\section{DALAM PERKARA INTERVENSI}

DALAM EKSEPSI

- Menolak eksepsi Tergugat I dalam intervensi untuk seluruhnya;

\section{DALAM POKOK PERKARA}

- Menolak gugatan Intervensi untuk seluruhnya ;

- Menghukum Penggugat Intervensi membayar biaya perkara sejumlah Nihil ;

Demikian diputuskan dalam sidang permusyawaratan Majelis Hakim Pengadilan Negeri Lubuk Pakam, pada hari JUMAT, tanggal 13 Mei 2016 , oleh kami, Dr. Henry Tarigan, S.H.,M.Hum., sebagai Hakim Ketua, Samuel Ginting, S.H.,MH., dan Halida Rahardhini, S.H.,M.Hum., masingmasing sebagai Hakim Anggota, yang ditunjuk berdasarkan Surat Penetapan Ketua Pengadilan Negeri Lubuk Pakam Nomor 10/PDT.G/2015/PN Lbp tanggal 01 Juli 2015, putusan tersebut pada hari SENIN, tanggal 16 Mei 2016 diucapkan dalam persidangan terbuka untuk umum oleh Hakim Ketua dengan dihadiri oleh para Hakim Anggota tersebut, Aristo Prima, S.H.., Panitera Pengganti, dengan dihadiri oleh dihadiri oleh Kuasa Hukum Tergugat I dan II/Tergugat II dan III Intervensi, Kuasa Hukum Tergugat III/Tergugat IV Intervensi dan Kuasa Penggugat Intervensi dan tanpa dihadiri Kuasa Hukum Penggugat/Tergugat I Intervensi.

\section{Analisis Hukum Putusan Nomor : 10/Pdt.G/2015/PN Lbp}

Putusan Hakim atau putusan pengadilan merupakan aspek penting yang diperlukan untuk menyelesaikan perkara perdata dengan demikian lebih jauh bahwasanya putusan hakim disatu pihak berguna untuk memperoleh ketetapan mengenai ahli waris yang sah bagi pihak yang menang dalam perkara, memperoleh kepastian hukum tentang status kepemilikan harta waris.

Putusan Hakim sangat dipengaruhi oleh dalil, bukti surat, saksi yang dilakukan oleh penggugat didalam 
sidang. Proses Peradilan akan berakhir dengan suatu putusan akhir. Dalam putusan tersebut Hakim menyatakan mengenai hal-hal yang dipertimbangkan olh hakim dalam putusan tersebut. Semua putusan pengadilan akan sah dan mempunyai kekuatan hukum apabila putusan tersebut diucapkan dalam sidang (diputuskan dalam sidang permusyawaratan Majelis Hakim Pengadilan Negeri Lubuk Pakam, pada hari Jumat, tanggal 13 Mei 2016.

Dasar pertimbangan hakim memutuskan perkara gugatan hak waris uang pertanggungan asuransi jiwa akibat tidak dicantumkan ahli waris sebagai pihak penerima waris dalam polis asuransi jiwa sehingga terdapat perbuatan melawan hukum yang melanggar hak subjektif penggugat yang secara sah sebagai istri (janda) dan anak dari si pewaris (si mati), melainkan pihak tergugat I dan II.

Keputusan majelis hakim pada kasus perkara No.10/Pdt.G/2015/PN Lbp sudah sesuai setelah mempertimbangkan dalil, bukti suratsurat dan keterangan saksi tersebut diatas. Putusan hakim merupakan pernyataan hakim sebagai pejabat negara yang diberi kewenangan. Pernyataan itu dicantumkan dalam amar atau diktum putusan dan dalam kasus ini penggugat merupakan ahli waris yang sah.

Hakim dalam putusan ini mengabulkan gugatan Penggugat untuk sebahagian, menyatakan bahwa tergugat I dan II bukan sebagai ahli waris yang sah dan berhak menerimanya adalah merupakan perbuatan melawan hukum (Onrecht Matigedaan) dengan segala akibat hukumnya, kemudian Menghukum Tergugat III untuk menagih kembali uang pertanggungan klaim meninggal dunia asuransi jiwa atas nama Kien Njen dengan Nomor Polis 25783625 sebesar Rp
599.193.062, 22 (Lima Ratus Sembilan Puluh Sembilan Juta Seratus Sembilan Puluh Tiga Ribu Delapan Puluh Enam Rupiah Dua Puluh Sen) yang telah diserahkan kepada Tergugat I dan Tergugat II tersebut atau setidaktidaknya menghukum Tergugat I dan II untuk menyerahkan uang pertanggungan klaim meninggal dunia asuransi jiwa atas nama Kien Njen dengan Nomor Polis 25783625 sebesar $\mathrm{Rp}$ 599.193.062, 22 (Lima Ratus Sembilan Puluh Sembilan Juta Seratus Sembilan Puluh Tiga Ribu Delapan Puluh Enam Rupiah Dua Puluh Sen) tersebut kepada Penggugat seketika, tunai dan tanpa syarat.

Hasil analisis penulis bahwa pertimbangan hakim dalam menutuskan perkara gugatan hak waris atas uang pertanggungan asuransi jiwa ini sudah tepat. Karena keputusan tersebut mengembalikan hak subjektif dan mempertahankan prinsip asuransi (insurable intrest) Dimana salah satu unsur pokok yang harus ada dalam insurable interest adalah bahwa "tertanggung harus mempunyai hubungan pokok pertanggungan dimana tertanggung tidak akan mengalami kerugian apabila pokok pertanggungan itu selamat dan sebaliknya akan mengalami kerugian apabila pokok pertanggungan itu mengalami kerugian dalam artian anak dan istri (ahli waris yang sah/ kelas pertama) akan mengalami masalah keuangan ketika pewaris meninggal dunia.

\section{SIMPULAN}

1. Kedudukan Penerima Manfaat (beneficiary) dalam asuransi jiwa merupakan pihak yang akan mengambil uang dari pihak penanggung terhadap perjanjian yang telah disetujui, pihak ketiga yang berkepentingan, disebut sebagai penikmat. Penikmat ini dapat berupa 
orang yang ditunjuk oleh tertanggung atau ahli waris tertanggung yang memiliki insurable interest (hak menurut hukum untuk mengasuransikan yang timbul dari hubungan finansial, yang diakui oleh hukum, antara tertanggung dan pokok pertanggungannya) haknya hanya sekedar menerima uang karena namanya tercantum dalam Polis Asuransi sebagai calon penerima manfaat dan bukan untuk memilikinya sedangkan ketika tertanggung/pewaris meninggal dunia uang santunan asuransi tersebut sesungguhnya adalah milik dan kepunyaanAhli Waris berdasarkan pada ketentuan Pasal 830 KUHPerdatayang menyebutkan bahwa "Perwarisan hanya berlangsung karena kematian", dimana ada 2 (dua) syarat yang harus dipenuhinya untuk dapat memiliki hak mewarisi, yaitu : harus ada orang yang meninggal dunia, danuntuk memperoleh harta peninggalan, orang harus hidup pada saat pewaris meninggal dunia.

2. Peerlindungan hukum ahli waris untuk mendapatkan haknya dapat melalui penyelesaian sengketa diluar pengadilan (Non Litigasi) dan di pengadilan (litigasi).Henriyani dan Shellyna Evelyn (Penggugat) melakukan langkah hukum dengan surat gugatan tanggal 23 Januari 2015 yang diterima dan didaftarkan di Kepaniteraan Pengadilan Negeri Lubuk Pakam pada tanggal 26 Januari 2015 dalam Register No:10/Pdt.G/2015/PN Lbp. Putusan Hakim, Mengabulkan gugatan Penggugat untuk sebahagian. Polis asuransi dapat dianggap sebagai harta warisan yang harus dibagi kepada para ahli waris sah menurut Undang-Undang karena termasuk dalam piutang (aktiva) yang akan didapat dari perusahaan asuransi. Putusan Nomor : 10/Pdt.G/2015/PN Lbp, berdasarkan beberapa pertimbangan majelis hakim memeriksa dan menjatuhkan putusan berpedoman pada dalil, saksi dan bukti yang diserahkan dalam persidangan. Putusan hakim memperoleh ketetapan mengenai ahli waris yang sah bagi pihak yang menang dalam perkara, memperoleh kepastian hukum tentang status kepemilikan harta waris yang berupa uang santunan dari asuransi jiwa kepada Ahli Waris yang sah.

\section{DAFTAR PUSTAKA}

\section{Buku-Buku}

Bachtiar.,Metode Penelitian Hukum, Unpam Press, Banten : 2018.

Hayati,Amal dan Haris, Rizki Muhamad, dan Hasibuan, Zuhdi., Hukum Waris, Manhaji, Medan : 2015.

Rahmi Ria Wati dan Zulfikar Muhamad., Hukum Waris Berdasarkan Sistem Perdata Barat dan Kompilasi Hukum Islam, Bandar Lampung : 2018.

Rastuti, Tuti.,Aspek Hukum Perjanjian Asuransi, Medpress Digital, Yogyakarta : 2016.

Rusman Ignatius., Pengantar Asuransi, Aca Akademi, Jakarta : 2018.

Salim, HS dan Septiana, Nurbani, Perbandingan Hukum Perdata, PT Raja Grafindo, Jakarta : 2014.

Sembiring, M. U., Beberapa Bab Penting dalam Hukum Waris menurut Kitab UndangUndang Hukum Perdata, Program Pendidikan Notariat FH USU, Medan : 1989

sintha devi ria, Perkembangan Hukum Dagang di Indonesia, CV. Sentosa Deli Mandiri, Medan, 2020. 
Sujono, dan Abdurahman, Metode Penelitian Hukum, Cetakan Kedua, PT Rineka Cipta, Jakarta : 2003

Subekti.,Pokok-Pokok Hukum Perdata, Intermasa, Jakarta : 2003.

Subekti R. dan Tjitrosubio R., Kitab Undang-Undang Hukum Perdata (Burgerlijk Wetboek), Balai Pustaka, Mataram : 2014.

Triwulan Tutik Titik,.Hukum Perdata Dalam Sistem Hukum Nasional, Kencana, Jakarta : 2011.

\section{Perundang-Undangan}

Kitab Undang-Undang Hukum Perdata Kitab Undang-Undang Hukum Dagang Herzien Inlandsch Reglement (H.I.R)Reglemen Indonesia Yang Diperbaharui (R.I.B.)

Undang-Undang Nomor 1 Tahun 1974

Tentang Perkawinan

Undang-Undang Nomor 40 Tahun 2014

Tentang Perasuransian

Peraturan Otoritas Jasa Keuangan Nomor $69 \quad /$ Pojk.05/2016 Tentang Penyelenggaraan Usaha Perusahaan Asuransi, Perusahaan Asuransi Syariah, Perusahaan Reasuransi, Dan Perusahaan Reasuransi Syariah

Makalah, Artikel, jurnal dan lainlain

Aji Surya Pratama, Abdul Halim Barkatullah, dan Rahmida Erliyani, Kedudukan Dana Asuransi Jiwa Dalam Relevansinya Dengan Pembagian Harta Warisan, Lambung Mangkurat Law Journal Vol. 4 No. 1 (2019)

ria sintha devi, Tinajaun Yuridis Perceraian Atas Perkawinan yang Tidak Tercatat Di Dinas Kependudukan dan Pencatatan Sipil Kota Medan, Jurnal Retentum Vol. 1 No. 1 (2019): Juli

, Tinjauan Yuridis Sita Jaminan dan Pemberesan Harta Milik Debitur Dalam Hal Terjadinya Kepailitan, Jurnal Ilmiah MAKSITEK Vol. 4 No. 4 (2019)

Suprima, Wardani Rizkianti, dan Khoirur Rizal Lutfi., Implikasi Hukum Penunjukan Ahli Waris Berdasarkan Klausul Asuransi Dalam Perspektif Hukum Waris Perdata, Jurnal Esensi Hukum Vol. 1 No.1 (2019)

Paendong H.K.V Perlindungan Pemegang Polis Pada Asuransi Jiwa Di Kaitkan Dengan Nilai Investasi Vol.I.No.6 (2013)

Yasir Fauzi, Muhammad., Legislasi Hukum Kewarisan di Indonesia, Jurnal Pengembangan Masyarakat Islam Vol. 9 No. 2 (2016)

\section{Internet}

Jufri, Zubaidah, Menghindari Potensi Sengketa Dalam Waris, https://siplawfirm.id/menghind ari-potensi-sengketa-dalamwaris diakses terakhir pada selasa 25 februari 2020 pukul 13.00 WIB

Nindyo, Fajar, Konsep Insurable Interest Pada Asuransi Jiwa, https://www.pojokasuransi.co $\mathrm{m} /$ konsep-insurable-interestpada-asuransi-jiwa/ diakses terakhir pada 22 Juni 2020 Pukul 10.49 WIB 